THEATRUM MUNDI Y EXALTACIÓN DEL HÉROE TRÁGICO EN LA VISITA EN EL TIEMPO DE USLAR PIETRI

\title{
Theatrum Mundi and Exaltation of the Tragic Hero in La visita en el tiempo by Uslar Pietri
}

ROBIN LEFERE

UNIVERSITE LIBRE DE BRUXELLES (Bélgica)

rlefere@ulb.ac.be

Resumen: Esta contribución se centra en la última novela histórica de Arturo Uslar Pietri, La visita en el tiempo (1990), con el fin de poner de relieve la especificidad semántica del discurso novelesco de la Historia y, en especial, de analizar el proceso de ficcionalización. En este marco, reflexiona sobre la tematización de la figura de Don Juan de Austria, desmitificado como héroe histórico y exaltado como héroe trágico; y, en particular, sobre las funciones y el alcance del topos literario - principalmente el theatrum mundi- en el proceso de tematización de la Historia.

Palabras clave: ficcionalización de la Historia, topos literario, Uslar Pietri, Don Juan de Austria

\footnotetext{
Abstract: This contribution focuses on A. Uslar Pietri's most recent historical novel, La visita en el tiempo (1990). It aims at highlighting the semantic specificity of the novelistic discourse of History, and more particularly at analyzing the process of fictionalization. Within this framework, the article reflects on the thematization of the Don Juan de Austria's figure (demythified as an historical hero and exalted as a tragic hero) and more specifically on the functions and the scope of the literary topos (mainly the theatrum mundi) in the process of History thematization. Keywords: Fictionalization of History, Literary Topos, Uslar Pietri, Juan de Austria
} 
[...] ninguna comparación hay que más al vivo nos represente lo que somos y lo que habemos de ser como la comedia y los comediantes $[\ldots]$

— ¿Brava comparación! — dijo Sancho-, aunque no tan nueva que yo no la haya oído muchas veces, como aquella del juego del ajedrez $[. .$.

Quijote, 11,12

Dieciséis años después de su muerte, el 26 de febrero de 2001, Arturo Uslar Pietri sigue siendo, en su vertiente literaria y al lado de sus numerosos relatos y ensayos, el gran escritor venezolano de novelas históricas. Se estrenó en el género de manera precoz y deslumbrante, con Las lanzas coloradas (1931). Tras esta obra maestra y renovadora, imaginada en el contexto de las búsquedas vanguardistas que compartía con sus amigos Miguel Ángel Asturias y Alejo Carpentier, Uslar Pietri volvería a cultivar dicho género — que, por cierto, no quería asumir como tal -' de manera periódica. Recordemos: El camino de El Dorado (1947), El laberinto de fortuna (con los subtítulos Un retrato en la geografía, 1962 y Estación de máscaras, 1964), ${ }^{2}$ Oficio de difuntos (1976), La isla de Róbinson (1981), y por fin su última novela, escrita a los ochenta y tres años, La visita en el tiempo (1990), que mereció el premio Rómulo Gallegos y por otra parte coincidió con la atribución del Premio Príncipe de Asturias de las Letras.

Dentro de este corpus de novelas históricas, cuya diversidad no podemos resaltar aqui, ${ }^{3}$ tres participan, con las debidas variaciones, de un mismo tipo fundamental ampliamente ilustrado desde el siglo XIX: el de la novela que se centra de manera explícita en una figura histórica documentada cuya perspectiva subjetiva acompaña un narrador heterodiegético "omnisciente". ${ }^{4}$ Estas figuras son, respectivamente, el conquistador Lope de Aguirre (El camino de El Dorado), el maestro (de Bolívar) Simón Rodríguez (La isla de Róbinson) y Don Juan de Austria (La visita en el tiempo).

Vamos a centrarnos en esta última y en la perspectiva que ofrece sobre su protagonista. No con la intención de contrastar novela biográfica y biografía académica, interrogándonos sobre la relación asimétrica entre ellas y, en especial, sobre el desinterés (por no decir el desprecio) de la segunda con respecto a la

\footnotetext{
${ }^{1}$ Por ejemplo, en una "conversación" con Antonio López Ortega: "Yo nunca me propuse hacer novelas históricas. Y yo siempre he objetado esa calificación de novela histórica” (1994: 410).

${ }^{2}$ Un retrato en la geografía y Estación de máscaras constituyen las dos primeras entregas de una trilogía inconclusa (Spinato, 2001: s/p) y se distinguen de las demás novelas históricas del autor por centrarse en el presente, que se enfoca con una perspectiva histórica $-\mathrm{y}$ por lo tanto se corresponde con nuestro concepto ampliado de la novela histórica (Lefere, 2013: 31-50).

${ }^{3}$ En el capítulo que dedica a Uslar Pietri en su Historia y ficción en la novela venezolana, Márquez Rodríguez distingue tres categorías (1991: 160-161), pertinentes en una primera aproximación: las "novelas propiamente históricas", donde se incluye las tres biográficas que hemos destacado y Las lanzas coloradas; las "pseudoficticias", es decir, "los sucesos y los personajes, tomados literalmente de la historia [...] aparecen de tal modo disfrazados, que en apariencia se trata de relatos enteramente imaginarios", como en Oficio de difuntos; y las "histórico-simbólicas", probablemente el único marbete que avalaría AUP, "novelas construidas en su totalidad como ficticias, con personajes y sucesos inventados por el autor, pero que de algún modo reflejan la realidad histórica de un momento o período determinado" (caso de El laberinto de fortuna).

${ }^{4}$ Utilizamos esta caracterización tradicional, pero con las debidas comillas distanciadoras: en general, no lo sabe todo pero sí tiene el don de ubiquidad y el privilegio de acceder a la vida mental de uno o varios protagonistas (si bien, a veces, fingiendo limitaciones).
} 
primera, ${ }^{5}$ sino con una doble voluntad: en primer lugar, la de poner a prueba el modelo descriptivo de la especificidad semántica del discurso novelesco que propusimos en otra ocasión (a propósito de El general en su laberinto), y, en segundo lugar, la de reflexionar sobre la función y el alcance del topos literario en el proceso de tematización de la Historia.

\section{Biografía histórica y novela histórica}

Si bien Uslar Pietri ha afirmado "[n]o me interesa la novela histórica, no leo ni he leído novela histórica, salvo las que leí en mis años juveniles. Lo que interesa es el Hombre" (Márquez Rodríguez, 1991: 148), no cabe duda de que, a la hora de proponerse la escritura de una novela centrada en la biografía de Don Juan de Austria, el autor se ha tomado la molestia de informarse cuidadosamente (como corresponde, puntualizaríamos). La novela abarca toda la vida de Don Juan (1545 o 1547-1578), con sus principales condicionantes —en especial su estatuto de hijo natural de Carlos V, por lo tanto hermanastro de Felipe II, con todo lo que esto implicó-, con sus principales peripecias e hitos: la represión del levantamiento morisco en Granada, la victoria de Lepanto, la gobernación de Flandes. Se puede afirmar que, globalmente, los datos que proporciona la ficción coinciden con lo que el lector curioso encuentra en la biografía académica de Sir Charles Petrie (Don John of Austria, 1967) o, incluso, en la más reciente de Bartolomé Bennassar (Don Juan de Austria. Un héroe para un imperio, 2004). ${ }^{6}$ En asuntos tan discutidos como la muerte del infante y amigo Don Carlos, donde la tradición literaria (la novelita de Saint-Réal y el drama de Schiller) y la llamada "leyenda negra" suelen reconocer la mano de un tétrico Felipe II, Uslar Pietri se muestra tan circunspecto como lo serían Joseph Pérez (1999) o Geoffrey Parker (2010). Sin embargo, La visita en el tiempo ofrece un discurso fundamentalmente distinto del de la biografía histórica, por no hablar de enfoques historiográficos más modernos. ${ }^{7}$ No se trata de historio-grafía ni de biografía propiamente dichas, ni siquiera de biografía novelesca o — sería reductor - de novela biográfica: es toda una novela histórica, es decir, antes que nada, toda una novela.

Llegados a este punto, conviene precisar algunos supuestos de nuestra aproximación a la novela histórica, que volvemos a poner a prueba a partir del caso de la novela considerada.

\section{Rasgos fundamentales del discurso novelesco de la Historia}

1. La visita en el tiempo no ofrece una "mezcla de ficción y de Historia", según la consabida y falaz fórmula. Se trata de una ficción, desde el título hasta la última línea; es decir, de un mundo autónomo generado por una instancia narrativa ficticia, anónima y distinta del autor, que goza de privilegios ficticios como la focalización cero. Paradójicamente, pues, se podría sostener que esta novela sobre Don Juan de Austria no es referencial, en el sentido de que la obra de ficción crea

\footnotetext{
${ }^{5}$ Perspectiva e interrogaciones que desarrollamos, a partir del caso de El general en su laberinto de Gabriel García Márquez, en "Sobre generales y laberintos: biografía académica y novela biográfica" (Lefere, 2013: 163-177).

${ }^{6}$ Cabe apuntar que, aunque Bennassar incluye un capítulo "Don Juan, mitificado" y, dentro de éste, un subcapítulo "Consagración de la literatura", el historiador se limita a evocar textos del Siglo de Oro (Fernando de Herrera, Alonso de Ercilla y Zúñiga, Góngora, Lope de Vega, y Cervantes) y, desde luego, no menciona en ninguna parte la novela de Uslar Pietri.

${ }^{7}$ Véase el poco espacio que ocupa el "héroe de Lepanto", e incluso la misma batalla de Lepanto, en la obra heterodoxa y luego clásica de Fernand Braudel, La Méditerranée et le monde méditerranéen à l'époque de Philippe ll (editada por primera vez en 1949).
} 
ella misma el mundo al que se refiere (Cohn, 2001: 27). Sin embargo, vamos a ver enseguida que conviene matizar.

2. Los numerosos datos históricos, en particular los relativos a Don Juan de Austria, son materiales extratextuales que integra la ficción, ficcionalizándolos; ${ }^{8}$ esto es, convirtiéndolos en componentes de una realidad ficticia y sometiéndolos a procesos semánticos sobre los que volveremos. Se produce por lo tanto un desdoblamiento de la referencia. El Don Juan de Austria de la novela es un ente textual y ficticio que pertenece al cuadro interno de referencia; como tal, su caracterización resulta irrebatible, por situarse más allá de lo verdadero y de lo falso. Esto no impide que el mundo ficcional pueda relacionarse con el extratextual, ni que el Don Juan de Austria intratextual se nutra del extratextual - como debe ser, diríamos- y pueda contrastarse con éste y el cuadro externo de referencia. Incluso cabe considerar que, en el caso de una novela histórica "propiamente dicha" (como es el caso), ${ }^{9}$ existe una doble intencionalidad referencial, radicalmente distinta: una intrarreferencial $y$, de manera indirecta y secundaria, otra extrarreferencial. ${ }^{10}$

3. Esta intencionalidad extrarreferencial es, a su vez, múltiple. En particular, antes que el referente histórico explícito, el autor suele tener "a la vista" una circunstancia histórica presente que condiciona y en cierta medida finaliza el discurso novelesco sobre el pasado. Éste aparece entonces como metafórico o simbólico, y proyecta sobre el presente una luz cuyo valor iluminador depende del grado de pertinencia de la analogía; el pasado también puede convertirse en referente mítico, en la medida en que se le reconozca el valor de causa originaria y siempre activa. En el caso de La visita en el tiempo, no resulta nada evidente la probable relación que mantiene el pasado evocado con la circunstancia presente, y el texto novelístico no parece aludir a ello. Propondríamos la hipótesis de que Uslar Pietri, que escribe su novela en vísperas de las conmemoraciones del Quinto Centenario del llamado "Descubrimiento de América", se adelanta de manera crítica pero indirecta e incluso implícita a los previsibles discursos españolistas (no asumidos como tales): no centrándose en el "encuentro" (encontronazo), sino, de forma parecida a lo que había hecho Homero Aridjis en 1492. Vida y tiempos de Juan Cabezón de Castilla (1985), en la realidad española previa al "descubrimiento", que iba a determinar las condiciones en que se llevara a cabo la colonización de América. Esto es, la realidad de un imperio que combate violentamente las diferencias religiosas $y$ culturales (el islam español y mediterráneo, el judaísmo, el protestantismo del Norte, las heterodoxias cristianas), y que padece graves problemas de identidad, precisamente en lo que a sus figuras más emblemáticas se refiere —en especial las de Carlos V, Felipe II, Don Carlos y, sobre todo, Don Juan de Austria."

\footnotetext{
8 ¿Hace falta precisar que por "extratextuales" entendemos "ajenos al texto de la novela”? Cenizas e iconografía aparte, Don Juan nos ha llegado a través de textos, y el personaje de la historiografía proviene de la elaboración textual (narrativa) de documentos.

9 Entendemos por "novela histórica propiamente dicha" una novela que tematiza principalmente la Historia; para una definición más precisa, y la discusión correspondiente, ver el primer capítulo de nuestro libro de 2013 (en particular las propuestas 3 y 5).

${ }^{10}$ Esta tensión entre extrarreferencialidad e intrarreferencialidad se refleja en esta puntualización de Uslar Pietri que recoge Márquez Rodríguez: "En lugar de hacer un monigote al que puedo añadirle o quitarle lo que quiera, prefiero tomar un ser vivo y transformarlo en personaje de novela" (1991: 148).

"Nos distanciamos por lo tanto de la hipótesis algo elíptica de E. Smith: "parecería que Uslar Pietri nos introduce en el campo metaficcional y en su temática recurrente: la búsqueda de la identidad latinoamericana; por todo esto ¿no es Don Juan de Austria una metáfora de América...?" (1996: 200).
} 
4. La ficción histórica se caracteriza por una tensión entre su estética fundamentalmente (intrar)referencialista, centrada en determinados referentes históricos ficcionalizados, y la tendencia hacia la simbolización propia de cualquier ficción. Hay que ver que lo que permite y favorece esta simbolización es precisamente el desdoblamiento de la referencia y la autonomía o, en todo caso, la prioridad del cuadro interno de referencia. Además, a través de éste se accede a la literatura en general puesto que sobre cualquiera de sus elementos gravitan no sólo la totalidad de la novela, sino, potencialmente, toda la obra de Uslar Pietri (intertextualidad homogénea) y toda la literatura (intertextualidad heterogénea).

Ahora bien, explicitados estos cuatro rasgos fundamentales que se complementan, conviene precisar el proceso de ficcionalización. De este proceso polifacético y complejo debemos limitarnos a comentar, parcialmente, dos principios esenciales: la "mise-en-intrigue" y la tematización.

\section{La "mise-en-intrigue"}

La "mise-en-intrigue" (emplotment) no debería confundirse con la que efectúa la historiografía - cuando ésta es narrativa, y según ha puesto de relieve la epistemología contemporánea al menos desde $\mathrm{H}$. White. En primer lugar, no se construye a partir de archivos y documentos, si bien los novelistas suelen citar fragmentos de cartas y otros géneros afines, ${ }^{12}$ sino a partir de discursos previos, en particular de una historiografía que ha convertido documentos en hechos establecidos. En segundo lugar, se puede decir que la mise-en-intrigue novelesca se distingue por sus objetos, el enfoque de éstos, y la lógica de la composición.

Los objetos: en el primer plano se sitúan personas ( $y$ no agentes, categorías institucionales, condicionantes históricos y geográficos), consideradas en sí y por su representatividad, en tanto que tipos humanos o sociales. ${ }^{13}$ Los protagonistas de la novela de Uslar Pietri se corresponden con personajes históricos pero, en su tratamiento, se combinan elementos establecidos, probables e inventados, sin hacer distinción entre ellos. Participa evidentemente de lo inventado todo lo que no está documentado, en particular los diálogos y monólogos, la vida interior (pensamientos, sentimientos, sueños). La visita en el tiempo consigue una "encarnación" (de papel) y una presentificación extraordinarias de Don Juan de Austria, gracias a los privilegios del enfoque narrativo ficticio: la perspectiva no personal y por lo tanto no situada (en el tiempo) y no limitada del llamado "narrador omnisciente" permite que acompañemos el punto de vista del protagonista ( $y$ no sólo de él) ${ }^{14}$ e incluso que seamos partícipes de sus percepciones y pensamientos.

En cuanto a la composición, no obedece necesariamente a principios racionales y menos aún a la preocupación de decir y explicar "lo que pasó". Por una parte, el tipo de mímesis (Il, según la terminología de Paul Ricoeur) resulta mucho más próximo a la mímesis espontánea $(1)^{15}$ que la historiográfica, que

\footnotetext{
${ }^{12}$ Uslar Pietri lo hace de manera muy moderada: véase el testamento de Carlos V, p. 41. La paginación remite a la edición Mondadori España, 1990, la más accesible pero desgraciadamente poco cuidada (son muchas las erratas).

${ }^{13}$ Véase en p. 81 cómo se presenta a Ruy Gómez de Silva (consejero de Felipe 11 y consorte, en segundas nupcias, de la Princesa de Éboli): en función de un principio de contraste con el temperamento contrario de Don Luis Quijada, y como encarnación del tipo del cortesano (puntualizando: "más tarde cuando leyó a Castiglione lo pudo comprender mejor").

${ }^{14}$ Un principio general de subjetivación se manifiesta desde el mismo íncipit de La visita en el tiempo: "Lentamente el pequeño grupo se puso en marcha por la cuesta abierta y terrosa en cuyo fondo asomaba [...] una mancha de paredes rojas. En medio, la litera de la señora oculta bajo el arqueado capacete" (11). Véase también la evocación de la batalla de Lepanto (pp. 180-183).

${ }^{15}$ Recordemos que la mímesis 1 se corresponde con la precomprensión o comprensión práctica de cualquier actuación, en función de una red conceptual tan espontánea como culturalmente
} 
precisamente procura emanciparse de la espontánea. Por otra parte, la perspectiva mimética está subordinada a la elaboración propiamente estética, que implica la construcción de un cuadro interno de referencia autónomo y de otros tipos de sentido, ${ }^{16}$ pero también la utilización de estrategias narrativas específicas cuya finalidad no es didáctica, sino, de manera más bien antipedagógica, pragmática: se trata de estimular la actividad del lector. En el caso de La visita en el tiempo, una estrategia recurrente, evidente desde la primera página, es la de empezar in medias res y de diferir la comunicación de informaciones pertinentes (para identificar a los personajes, con sus respectivas circunstancias). Otra opción llamativa del autor, en una diégesis globalmente lineal que se refiere a la trayectoria biográfica del protagonista, es la de empezar su relato con la visita del joven Jeromín (el futuro Don Juan de Austria) a Carlos $V$ retirado en su monasterio de Yuste; gracias a la prolepsis se promueve como emblemático un episodio que luego será recurrente en la memoria del personaje de Don Juan, y concluirá la novela (extinguiéndose con la muerte del protagonista). Esta composición circular, que se apoya en una segmentación del texto en capítulos y subcapítulos sin títulos, se corresponde con la tematización.

\section{Desmitificación del héroe histórico y exaltación del héroe trágico}

La intención del texto $-\mathrm{y}$, podemos añadir, la del autor- no es representar la vida del Don Juan de Austria extratextual (aunque lo hace también, con las debidas licencias poéticas), ${ }^{17}$ sino, a partir de éste, o más bien de la semblanza historiográfica de éste, convertido en símbolo de una circunstancia humana paradigmática, tematizar una problemática psicológica y existencial: el déficit de identidad y la dinámica comportamental que genera. ${ }^{18}$

El déficit de identidad, en el caso presente debido al qui pro quo con respecto a la identidad de los padres, a la condición de bastardo, y luego al estatuto de Príncipe a medias, genera una obsesiva necesidad de autoafirmación - tan decidida como insegura- y un insaciable, y suspicaz, afán de reconocimiento. La situación se complica, y se enriquece desde el punto de vista literario, cuando el reconocimiento social depende de la decisión de un hermano mayor con quien mantiene una relación de competencia y que, como Rey y en ausencia del padre común (había muerto Carlos V), funciona como Padre simbólico. Además, el rey prudente actúa como castrador frente a sus posibles rivales reales (Don Carlos y luego Don Juan), provocando en éstos pulsiones

determinada que incluye las nociones de acción, actor, finalidad, motivo, circunstancia, interacción. Esta precomprensión constituye, pues, una pre-“mise en intrigue", sin la cual no se podría efectuar la mímesis 11 o "mise en intrigue" propiamente dicha (Ricoeur, 1983: 108-135).

16 Cabe señalar la multiplicación de las imágenes, con ejemplos sugerentes de metáforas continuadas (que, por ejemplo, transfiguran la batalla de Lepanto, pp. 178-181), y la integración de elementos mágicos o maravillosos (las ciencias ocultas y la figura de Fausto; demonios y fantasmas; piedra filosofal y unicornio), que sin duda reflejan aspectos de la mentalidad de la época pero también se corresponden con el interés del autor por el "realismo mágico" — sabido es que Uslar Pietri difundió la noción en el ámbito hispanoamericano-, y con una seña de su identidad literaria.

${ }^{17}$ Una de las más notables se da cuando el joven Don Juan, en su huida hacia Barcelona, llega a una posada donde "pudieron ver un grupo numeroso que, entre gritos de burla, lanzaba en la manta al aire y recogían a un gordo campesino [...]. Por la puerta de campo asomó un viejo flaco a caballo, figura de burla, con una rota armadura, un casco raro y una lanza remendada" (97). Por aquel entonces no había sido creada aún la pareja cervantina, y de haberlo sido, quedaría la licencia del encuentro supuestamente histórico con personajes ficticios.

${ }^{18}$ En la citada entrevista con Antonio López Ortega, Uslar Pietri precisa: "me di cuenta de que era uno de los personajes que había tenido uno de los más graves problemas de identidad en el mundo" (1994: 410). 
edípicas, en la doble vertiente asesina e incestuosa..$^{19}$ El mayor deseo de Don Juan, el hijo ilegítimo, es imponerse, en el plano moral y gracias a sus dotes de guerrero, como el verdadero y legítimo heredero de Carlos V. Buscando este imposible reconocimiento, a lo largo de su vida Don Juan visita - en sus sueños o ensoñaciones - ${ }^{20}$ al Emperador, o auspicia la visita nocturna de éste.

Así pues, si bien la novela recoge todas las señales externas de la glorificación del héroe de Lepanto - discursos encomiásticos que lo emparentan con héroes mitológicos e históricos; estatuas, pinturas-, el énfasis está en la progresiva degradación de esa imagen $y$, sobre todo, en la fractura creciente entre dicha imagen - ansiosamente perseguida y a duras penas conseguida- y la conciencia amargada de quien acaba viéndose como "rey de los locos, con su cetro de payaso" (255). La gloria de Don Juan de Austria queda desmitificada como logro fugaz de una frustración íntima, y pasa a constituir una etapa típica en la trayectoria del héroe trágico.

En efecto, no sólo es trágica la situación inicial de Don Juan, en especial por encerrar una fatalidad psicológica (con sentimientos fratricida y parricida) y asignarle un destino, sino que se combina con el esquema de grandeza y decadencia, y la carrera hacia una muerte precoz; un futuro indirectamente recordado a través de las diversas profecías que se le hacen. Además, el protagonista se nos presenta con rasgos típicos del héroe trágico desde Sófocles: grandeza, hubris, catarsis, hamartia, pero también el sentimiento del destino (véanse 150-151, 219 etc.) y la errancia en busca de la identidad propia.

Estos apuntes deberían de bastar para dejar claro que el Don Juan de Austria de La visita en el tiempo es un personaje fundamentalmente literario. Pero resulta más evidente aún si consideramos que Uslar Pietri interpreta el déficit de identidad de su protagonista a través de tres figuras literarias apenas posteriores que enfoca desde esa misma perspectiva - Hamlet y Segismundo, pero también Don Juan (Tenorio)—, ${ }^{21}$ y que por lo tanto aquél vendría a prefigurar. El autor confirmó el deliberado emparentamiento, pero está implícito en el tratamiento del personaje y tiende a explicitarse a través de la intertextualidad, bien con alusiones (en lo que se refiere a Hamlet y a Segismundo) ${ }^{22}$, bien con un pasaje tan directo, aunque disfrazado, como es la escena en que el seductor Don Juan de Austria, llevado de la mano de su confesor, presencia en el atrio de una iglesia un auto que lo enfrenta con las burlas amorosas del conde Aurelio y su castigo final, en un cementerio, del brazo (de piedra) del padre de una de sus víctimas (201-202). ${ }^{23}$

La superposición de tres héroes trágicos tan célebres a la figura de Don Juan de Austria exalta a éste como héroe trágico, al mismo tiempo que desdibuja

\footnotetext{
${ }^{19}$ Don Juan, como Don Carlos, deseó a lsabel de Valois, mujer de Felipe ll. Y cuando, más tarde, en Namur, se le acerca Margarita de Valois, leemos: "Era, sobre todo, la princesa que la reina madre de Francia había propuesto a Felipe 11 para reemplazar a lsabel muerta. [...] A través de ella [Don Juan, que luego iba a poseerla] percibía otros rostros. Isabel de Valois, aquel sueño de mujer inaccesible de sus años mozos" (260-261).

${ }^{20}$ Por ejemplo: "En el sueño había momentos en que estaba solo con él [...] Quería volver a la alcoba y volvía todo el tiempo en un sueño despierto que lo mantenía como ausente" (37-38).

${ }^{21}$ Recordemos que Hamlet, La vida es sueño y El burlador de Sevilla son respectivamente de 1598 (o 1601), 1635 y 1630. Esta intertextualidad, recalcada por el mismo Uslar Pietri (Márquez Rodríguez, 1991: 149), ha sido explotada por Marbán (1994): valiéndose de ella habla, de manera algo abusiva, de "estructuras" míticas.

${ }^{22}$ "Entonces soy y no soy un príncipe" (70); "era sólo él quien estaba puesto en duda, quien podía ser o no ser" (113).

${ }^{23}$ Puesto que encontramos algunos episodios anacrónicos (sobre la referencia ambigua al conde de Orgaz, véase Márquez Rodríguez, 1991: 155-156), Uslar Pietri hubiera podido acudir a El burlador de Sevilla, pero ha preferido intrigar al lector evocando una variación italiana: L'ateista fulminato, que pertenece al repertorio de la commedia dell'arte. Por otra parte, hay que tener en cuenta que algunos historiadores consideraron que Tirso se inspiró en los desenfrenos italianos de Don Juan de Austria (Marbán, 1994: 37).
} 
la frontera ontológica entre criaturas literarias e históricas. Esta indiferenciación está en consonancia con las dudas existenciales de Don Juan de Austria - como de Segismundo y Hamlet- ${ }^{24}$ pero también con la temática del theatrum mundi.

\section{Theatrum mundi: la vida como juego}

Llegado a la corte de Valladolid y convertido en "Don Juan de Austria", Jeromín se franquea con su tía. Conviene citar el párrafo:

Tía, me siento como si estuviera haciendo un papel en una comedia. Ayúdame a hacerlo bien. "No es ningún papel, es vuestro verdadero ser" ¿Era su verdadero ser o era un simulador? Como si se hubiera disfrazado o como si hubiera estado disfrazado toda la vida. Nunca sabía si lo estaba haciendo bien [...]. Si no era el vergonzoso en palacio de la conseja. (74)

El cambio repentino de identidad y de estatuto determina esta duda existencial del protagonista, que lo lleva a considerarse como un actor de teatro y a emparentarse con un personaje ficticio. ${ }^{25}$ Duda y sospecha perdurarán y se generalizarán: Don Juan de Austria tiende a (a)percibir y sentir la vida (humana) como un drama teatral — tragedia $(105,121)$, comedia (trágica; 74, 266)—, una farsa para títeres (176; ver también 14, 91), una mascarada $(245,249)$, un carnaval (donde "hace de rey de los locos", 255). Diversas peripecias personales, así como la multiplicación de las representaciones artísticas del héroe (que lo confunden tanto como lo exaltan), no pueden sino reforzar este sentimiento, pero también vemos que lo comparten otros personajes. Varias circunstancias permiten comprenderlo: el contexto de una vida de corte que supone la simulación y donde, por otro lado, se multiplican los espectáculos (fiestas diversas, bailes de máscaras y entradas que resalta la novela); el contexto más amplio de una época en que los artistas multiplican los retratos analógicos, que identifican a los seres humanos con figuras mitológicas o bíblicas, y asimismo las representaciones simbólicas que condenan la vida mundana y las locuras humanas (como en la pintura del Bosco evocada, p. 243); por fin, una época en que se asienta, especialmente en España, el viejo tópico filosófico, religioso y literario del theatrum mundi. ${ }^{26}$

Ahora bien, muy presente en la novela, este tópico requiere más que una simple explicación en términos de motivación realista. En efecto, no se desarrolla principalmente desde la perspectiva de Don Juan ni de ningún otro personaje (y tampoco desde la del narrador, que se limita a acompañar puntos de vista subjetivos) ${ }^{27}$ quien más trascendencia le da, es el autor, al potenciar esa temática $y$, en particular, al proyectar sobre su protagonista, a quien tiende a identificar con ellas, las figuras de Hamlet, Segismundo y Don Juan, es decir, no sólo tres criaturas ficticias y teatrales, sino tres personajes que, con diversas modulaciones, dan cuerpo al tema del theatrum mundi. Esto es: la justificación realista funcionaría más bien como coartada.

\footnotetext{
${ }^{24}$ Lo recalca Uslar Pietri en la entrevista con Antonio López Ortega: “Hamlet nunca sabe cuál es la realidad, Hamlet vive continuamente entre una realidad y una sobrerrealidad; Segismundo no sabe quién es él" (1994: 410).

${ }^{25}$ Uslar Pietri menciona "una conseja", pero alude por supuesto a la futura comedia palatina de Tirso de Molina, El vergonzoso en palacio.

${ }^{26}$ Sobre la historia de ese topos (y de los valores que conlleva), véanse A. Vilanova (1950) y R.E. Curtius (1953), pero también las referencias más recientes que comenta G. Navaud (2011), quien reflexiona sobre el tema desde la perspectiva de la "metaforología" de Hans Blumenberg.

${ }^{27}$ En pocas ocasiones cabe la duda de si un comentario puede ser atribuido al narrador (y no a un personaje cuya perspectiva acompaña). Una de éstas es la siguiente; cuando Don Juan y Margarita de Valois llegan a la cámara de ésta, se comenta: "A la luz de los candelabros se alzaba el gran lecho dorado cubierto de cortinas, como la escena de un teatro" (262).
} 
De hecho, el tema aparece en otras novelas de Uslar Petri y, sobre todo, debe articularse con otro aspecto de la tematización: la metaforización de la vida como juego, que convierte a éste en tema fundamental. Las referencias al juego son numerosas y diversas. Pueden ser generales y abstractas, como cuando se habla del juego de la política y de la guerra $(136,243)$, del "juego del poder y de la muerte" (273), o del "juego de apariencias y negaciones" (104) que afecta tanto a Don Carlos como a Don Juan. La analogía se concreta a través de la evocación de diversos juegos tradicionales: la competencia entre pretendientes a tronos se compara con un "juego de las esquinas" (76), "un juego de escamoteo" o un "juego de sillas musicales" (221); el inocente "juego de la gallina ciega" se convierte en un tanteo funesto del destino (121). Asimismo, la Historia se compara a una partida de ajedrez: "Los maestros que les [a Don Carlos y Don Juan] explicaban la historia la describían como un misterioso y terrible juego entre la voluntad de los reyes y la de Dios. Los reyes hacían combinaciones matrimoniales [...] pero Dios, en el terrible ajedrez de la vida y de la muerte, las desbarata" (86; ver también $p$. 76). Ahora bien, donde la analogía se desarrolla de la manera más extraordinaria y sugerente es en la evocación de una partida de cartas, descrita por un narrador que supuestamente acompaña la perspectiva de Don Juan:

En las partidas de juego experimentaba aquella vertiginosa sensación del oscuro destino abierto ante sí. Atreverse, arriesgarse, dominar a los otros, correrlos y vencerlos, sentir la presencia del peligro o tratar de reponerse de la derrota. [...] La voltereta apagada de los dados sobre el tapiz era la imagen misma de la variable fortuna. El juego de la vida, que en el ordinario tomaba tiempo para resolverse, allí se decidía en momentos. [...] Todo estaba allí, más visible y claro que en la vida ordinaria. (150-151)

El proceso analógico se desarrolla a lo largo de dos páginas que mezclan, equiparándolas, bazas políticas y lúdicas: en torno al "tapiz del mar", en la preparación de la gran batalla contra el turco, los venecianos actúan como "fulleros de mal envite que escondían cartas en la manga"; de tal manera que se convierten las cartas (con sus figuras de reyes, caballos, espadas, oros, que se detallan) y la dinámica del juego en una sugerente imagen simbólica de la dinámica de la vida ( $y$ de la fortuna), con la diferencia de que aquí todo resulta "más visible y claro que en la vida ordinaria".

Esto sería lo esencial: las cartas de la baraja española (como las del tarot, evocadas justo después), se reinterpretan como juego mimético, para constituir una imagen infinitamente simplificada de la vida, que reduce infinitamente las dimensiones del tiempo y del espacio así como el número de actores, condicionantes y bazas; por lo tanto, y también gracias a las reglas que definen el juego, las cartas ofrecen la "ilusión del dominio". Por otra parte, en virtud del carácter jeroglífico de sus figuras, y de un azar reinterpretado como manifestación de la Fortuna o del Destino, las cartas conllevan una "promesa de sentido". Vemos el vínculo con el teatro, que sin duda constituye un juego de tipo muy distinto, ${ }^{28}$ pero que él también, sin perjuicio para su riqueza humana, propone del mundo una imagen infinitamente simplificada: un mundo reducido al espacio de un escenario con sus modestos bastidores, y un tiempo reducido al de la representación y de la acción. Ofrece, más allá de la ilusión (de vida y de dominio de ésta), una promesa de sentido: gracias al valor ejemplar de la acción y a la riqueza potencial del discurso, y gracias a la instancia metafísica que sugiere el símil ("Dios", si acaso ex machina).

\footnotetext{
${ }^{28}$ Según la perspicaz tipología que propone R. Caillois en su clásico ensayo Les jeux et les hommes, el teatro se define por la mimicry, mientras que los juegos de cartas por la alea y el agôn (1967: 47-67).
} 
En ambos casos, pues, si bien la analogía desempeña una función realista (mimética con respecto al mundo mental de Juan y de su época), está claro que, al desarrollarse de manera tan estructural, coherente y sugerente, va mucho más allá; cabe pensar que la asume el autor, al menos por esas otras dos funciones ilusión de dominio y promesa de sentido- que son propias de los juegos considerados (el teatro y las cartas), pero también de la literatura (del juego literario). De hecho, La visita en el tiempo en su conjunto puede ser enfocada como otra representación lúdica simplificadora, que satisface deseos tradicionales del lector (dominar, comprender) y del autor (quitar peso al mundo y dominarlo, darle sentido).

Conviene subrayar que la satisfacción de esos deseos, en especial la construcción del sentido, se apoya en el lugar común: en el sentido retórico de forma de razonamiento, y en el sentido más actual de cliché o estereotipo. La analogía común o estereotipada del theatrum mundi y del juego de cartas ayuda a entender, de forma sintética y tal vez ilusoria, la Historia y, por lo tanto, contribuye de manera eficaz a la satisfacción del deseo de sentido, por lo menos ofreciendo lo que Borges hubiera llamado el "sabor del saber". Asimismo, esas analogías, por lo que implican de repetición regulada, espacialización, unidad y totalidad, satisfacen el deseo de totalización unitaria que suele animar la práctica artística y se manifiesta aquí en la estructura de la obra realizada, como en otras expresiones del imaginario. En una novela histórica donde las fechas brillan por su ausencia, se insiste en que todo lo que vio, oyó, recordó y adivinó Juan de Austria "se fue mezclando en las horas y los años hasta formar una eternidad sin principio ni fin" (38), y, a lo largo de su breve existencia, el protagonista repite, mentalmente, obsesivamente, la visita que de joven le hizo a Carlos, de tal manera que ésta se convierte en escena originaria y determinante, de la que se deriva y a la que devuelve toda una vida. Por otra parte, en las páginas admirables que se dedican a la batalla de Lepanto (evocada desde un punto de vista que tiende a extralimitar el de Juan), leemos que los soldados de un mismo bando "eran como un solo hombre repetido centenares de veces" (179), que la selva de arboladuras hace pensar en la "confluencia de muchos torrentes humanos, que había llegado allí [...] a confundirse y mezclarse en un mismo momento y en un mismo impulso" (180), de tal forma que los contrincantes llegan a confundirse: "cada espolón, erguido y cabeceante, buscaba los bajos blandos de la otra galera. Era como una manada de bestias marinas en celo"; "quedaron trabadas en un solo movimiento" (181).

\section{Topos literario y metáfora heurística}

La interpretación de los topoi del theatrum mundi y de la vida como juego (de cartas) resultaría incompleta si, además de poner de relieve sus diversas funciones semánticas, y en particular la de recurso retórico para facilitar la construcción de sentido y la adhesión del lector, no nos preguntáramos si La visita en el tiempo reconoce en ellos el valor de "metáforas esenciales" (Borges) o "metáforas absolutas" (H. Blumenberg); es decir, de metáforas que, por plasmar intuiciones que se remontan a la "noche de los tiempos" - y a través de esas imágenes sugerentes se repiten, como si las confirmaran las sucesivas generaciones- ${ }^{29}$ y por considerarse irreductibles al discurso racional o logos (por su talante intuitivo pero también sintético), se reputan "heurísticas" (Ricoeur).

\footnotetext{
${ }^{29}$ Navaud apunta con acierto que la metáfora absoluta suele presentarse como una "métaphore filée formant à terme un paradigme ou un mythe" (2011: 12); se puede puntualizar que tal "metáfora continuada" se continúa también a lo largo del tiempo, en los textos que la perpetúan con variaciones enriquecedoras.
} 
Desde luego, la novela no se limita a perpetuar el tópico del theatrum mundi, utilizándolo para los fines que hemos visto, sino que parece confirmar su pertinencia cognitiva al asociarlo con un personaje histórico que, en su realidad extratextual, tuvo que asumir un papel en la comedia de la vida palaciega, al intentar demostrar a los demás y demostrarse a sí mismo que estaba a la altura. Es más: potencia el topos al emparentar dicho personaje (Don Juan de Austria) con tres figuras teatrales (Don Juan, Segismundo, Hamlet) que - según la perspectiva ofrecida, ilustrando un valor propiamente heurístico de la metáforavenía a prefigurar en la misma Historia. También se potencia al proyectarse, sobre el papel del actor, el del jugador, con el tópico afín que conlleva (la vida como juego) y que, como hemos visto, se trabaja asimismo (los juegos proliferan en los planos literal y figurado), de tal manera que se refuerzan mutuamente ambos campos metafóricos. Se puede sostener, pues, que la novela toma en serio sus dos topoi principales, que, por cierto, habían sido remozados por las ciencias humanas (pensemos en los ensayos clásicos de Huizinga y Caillois); incluso les reconoce un valor de metáforas heurísticas. Ahora bien, de la tradición interpretativa La visita en el tiempo no recoge la vertiente teológica y escatológica (como en la tradición cristiana, especialmente barroca), sino la ética (como en la tradición estoica): las metáforas plantean - permiten volver a plantear - las cuestiones de la identidad y de la autenticidad, de la libertad, invitando a pensar (y así lo entiende este Don Juan de Austria) que, puesto que el hombre no controla ni su condición de actor ni la trama del drama, su única libertad ( $\mathrm{y}$ su autenticidad, y a la postre su identidad) está en cómo va desempeñando el papel que le toca.

\section{BiBLIOGRAFÍA}

Bennassar, Bartolomé (2004), Don Juan de Austria. Un héroe para un imperio. Madrid, Temas de Hoy.

Blumenberg, Hans (2006), Paradigmes pour une métaphorologie. París, Vrin.

BRAUDEL, Fernand $\left(1985^{6}\right)$, La Méditerranée et le monde méditerranéen à l'époque de Philippe II. París, Armand Colin.

CAllLols, Roger (1967), Les jeux et les hommes: le masque et le vertige. Paris, Gallimard.

CoHN, Dorrit (2001), Le propre de la fiction. París, Seuil.

CURTIUS, Ernst Robert (1953), European Literature and the Latin Middle Ages. Londres, Routledge \& Kegan Paul.

HuIZINGA, Johan (1938), Homo ludens. Proeve eener bepaling van het spel-element der Cultuur. Haarlem, H.D. Tjeenk Willink \& Zoon.

LEFERE, Robin (2013), La novela histórica: (re)definición, caracterización, tipología. Madrid, Visor.

LÓPEZ ORTEGA, Antonio (1994), "Venezuela: Historia, política y literatura (conversación con Arturo Uslar Pietri)", Revista Iberoamericana, vol. LX, n. ${ }^{\circ}$ 166-167, pp. 397-414. DOl: <https://doi.org/10.5195/reviberoamer.1994.6512>.

MARBÁN, Jorge (1994), "La visita en el tiempo de Arturo Uslar Pietri: estructuras míticas en una novela histórica", Explicación de textos literarios, vol. XXII, n. ${ }^{\circ}$, pp. 35-41.

MÁRQUEZ RoDríguEZ, Alexis (1991), Historia y ficción en la novela venezolana. Caracas, Monte Ávila.

NAvauD, Guillaume (2011), Persona. Le théâtre comme métaphore théorique de Socrate à Shakespeare. Genève, Droz.

PARKER, Geoffrey (2010), Felipe II. La biografía definitiva. Barcelona, Planeta.

PÉREZ, Joseph (1999), L'Espagne de Philippe II. París, Fayard.

PETRIE, Sir Charles (1967), Don John of Austria. Londres, Eyre \& Spottiswoode. 
Ricoeur, Paul (1983), Temps et récit. l. L'intrigue et le récit historique. París, Seuil. SMITH, Esther (1996), "La novela en la historia: un encuentro metaficcional", en Mignon Domínguez (ed.), Historia, ficción y metaficción en la novela latinaomericana contemporánea. Buenos Aires, Corregidor, pp. 187-202.

SpINATO, Patrizia (2001), "La trilogía inconclusa de Arturo Uslar Pietri", en Biblioteca Virtual Miguel de Cervantes. Consultado en <http://www.cervantesvirtual.com/obra/la-trilogia-inconclusa-de-arturo-uslarpietri--0/> (5/8/2017).

VILANOVA, Antonio (1950), "El tema del gran teatro del mundo", Boletín de la Real Academia de Buenas Letras de Barcelona, XXXIII, pp. 153-188. 